\title{
RESTORATION OF THE SEPARATE ESTATE FROM COMMUNITY PROPERTY \\ AFTER THE EQUAL MANAGEMENT REFORM: SOME THOUGHTS ON LOUISIANA'S REIMBURSEMENT RULES
}

\author{
Cynthia Samuel
}

\section{INTRODUCTION}

"The problem of how best to preserve the individual wealth of the spouse during the continuance of the marital partnership is one of the important unsolved problems of community property law."1 So wrote Professor W.O. Huie in 1953 apropos of Louisiana's jurisprudence, which at that time attempted to protect the wife by making it difficult for the husband, the sole and exclusive manager of the community property, to recover his separate estate by reimbursement. When Louisiana shifted from husband management to a general rule of equal management of the community property in 1980 , gender-specific protection in the reimbursement rules was appropriately jettisoned. The 1980 reimbursement rules are also more sympathetic to separate reimbursement claims than to safeguarding a spouse's interest in the community property. The rationale behind the rules is that the spouses' common endeavor, the community property, will be protected by permitting both spouses equally and independently to manage the community. The legislature apparently concluded that there was no longer a need for the reimbursement rules to protect the community property when a spouse seeks reimbursement of his or her separate estate. As the cases are beginning to show, however, the disposition of separate claims for reimbursement under the 1980 rules can be devastating on a spouse whose means consist of only his or her interest in the community property. Louisiana now has a new "unsolved problem," the reverse of the old one: how best to preserve the community from the restoration of a spouse's separate estate at termination of the community regime.

The theme of the 1980 revision of Louisiana management rules was clearly one favoring the independence of both spouses. A major concern was whether a spouse should be able to manage and obligate more community property than

\section{Copyright $(\mathcal{O} 1993$ by Law and Contemporary Problems}

* Professor of Law, Tulane University.

The author wishes to thank Professor A.N. Yiannopoulos for his helpful comments on the manuscript and for the encouragement he has always shown the author throughout her career.

1. W.O. Huie, Separate Claims to Reimbursement from Community Property in Louisiana, 27 TUL. L. REV. 143 (1953). 
he or she alone had produced. Out of concern for the independence of a nonearning or lesser-earning spouse, Louisiana adopted equal management as the general management rule and rejected the Texas-style "two funds" or "separate but equal" management system. ${ }^{2}$ Under Louisiana's equal management rule, either spouse acting alone may manage and dispose of community property and obligate the community property for debts, whether the debts be for community or separate purposes. ${ }^{3}$ Whether the community property a spouse seeks to manage or obligate was produced by that spouse is irrelevant. ${ }^{4}$

The management rules, however, are by no means unbalanced in favor of independence. They are replete with exceptions where the independence of both spouses or the independence of one spouse is limited for the spouses' common good or to make the community regime workable vis-à-vis third persons. The rules consider certain assets, such as immovables (that is, real estate) and furnishings located in the family home, too important to the common endeavor to be left to the independent authority of a spouse to manage and dispose. The spouses must concur for the alienation, encumbrance, or lease of these assets. ${ }^{5}$ Likewise, concurrence is required for donations of community property other than ordinary and customary ones. ${ }^{6}$

Similarly, in certain instances one spouse is permitted to have exclusive management. ${ }^{7}$ Commercial laws necessitated an exception for a spouse in whose name community movables were titled, and the need for stability in the direction of a business prompted an exception for the spouse who was in fact managing a community enterprise without the participation of the other spouse.

The rules regulating the interspousal claim for the restoration of a spouse's separate estate at termination of the community regime offer a startling contrast to the balanced management rules. One might have expected a finely tuned compromise of the sometimes conflicting goals of the spouses as independent people and as members of a common endeavor. Instead, Louisiana's rules are quite simple and are designed to facilitate restoration of the separate estate, usually through reimbursement, with few qualifications or limitations. ${ }^{8}$ A separately wealthy spouse can restore his or her separate property at the expense of the other spouse's interest in the community property in Louisiana more easily than in other community property states or under pre-1980 Louisiana law. In

2. See Katherine Spaht, Background of Matrimonial Regimes Revision, 39 LA. L. REV. 323, 331-45 (1979); George Bilbe, Management of Community Assets Under Act 627, 39 LA. L. REV. 409, 410 (1979). See generally J. Thomas Oldham, Management of the Community Estate During an Intact Marriage, 56 LAW \& CONTEMP. PROBS. 99 (Spring 1993).

3. LA. Civ. CODE ANN. arts. 2345-46 (West 1985).

4. Such an inquiry is relevant in Texas. See TEX. FAM. CODE ANN. $\$ \S 5.22,5.61$ (West 1975 \& Supp. 1993).

5. LA. CIv. CODE ANN. art. 2347 (West 1985).

6. Id. art. 2349 (West 1985).

7. Id. arts. 2350-51 (West 1985).

8. See id. arts. 2360-63, 2365, 2367 (West 1985 \& Supp. 1992), discussed infra text accompanying notes $16-43$. 
some instances, the wealthy spouse may impose on the other spouse a personal obligation for reimbursement beyond the value of the community property.

This article argues that Louisiana's rules on restoration of the separate estate need some modification. Restoration is consistent with Louisiana's ganancial system of community property, wherein only the gains, if any, from the common endeavor, and not the separate capital of the spouses, are shared at termination of the regime. ${ }^{9}$ Restoration is also consistent with Louisiana's position that donations are not presumed $;^{10}$ restoration of separate property therefore cannot be denied on the ground that the property was presumptively donated. However, especially now that a spouse's interest in the community property may be the only durable source of financial security at divorce, ${ }^{11}$ a rule that allows that interest to be obliterated easily by the reimbursement claim of the separately wealthy spouse must be questioned. Neither gender neutrality nor the general rule of equal management precludes refinements in the reimbursement rules designed to balance independence and common purpose. Part II of this article looks at the present Louisiana law both as it appears in the Civil Code and as it has been applied by the courts. Part III compares past Louisiana law to discern which considerations, other than gender, were once thought relevant to the restoration of the separate estate. Parts IV and V examine two equal management jurisdictions with codified law on the subject of restoration of the separate estate, California and France, for the light they shed on the problem. Louisiana's own recently enacted law of co-ownership is analyzed in Part VI. Finally, Part VII recommends amendments to the Louisiana Civil Code.

9. See Nina N. Pugh, The Spanish Community of Gains in 1803: Sociedad de Gananciales, 30 LA. L. REv. 1, 34 (1969); W.O. Huie, Separate Ownership of Specific Property Versus Restitution from Community Property in Louisiana, 26 TUL. L. REV. 427 (1952). Spanish authorities, however, would not have allowed reimbursement where separate funds were lost due to the fault of the owner or for necessities the husband was obligated to provide the wife. Pugh, supra this note, at 29. Furthermore, the authorities were divided on whether separate funds brought to the marriage and used for the community were considered a donation or, alternatively, a loan to be reimbursed. Id. at 7 .

10. Broussard v. Broussard, 340 So. $2 d 1309$ (La. 1976). See also LA. CIv. Code ANN. art. 2343.1 (West 1985), which requires a gratuitous transmutation of separate property to community to be made by authentic act (that is, a formal document executed before a notary public and two witnesses).

11. The extent to which Louisiana already has abandoned the concept of alimony as a pension in favor of the concept of rehabilitative alimony is unclear. The Civil Code mandates the divorce court to consider - when alimony is sought - the claimant's earning capacity and the time it would take to acquire appropriate education, training, or employment. LA. CIV. CODE ANN. art. 112 (West Supp. 1992). Thus, a spouse with present earning capacity might not receive any alimony. As for potential earning capacity of the claimant, lower courts have interpreted the Code as permitting an award of alimony with an automatic cut off date based upon an estimate of how long it should take the claimant to become self-supporting, but the Louisiana Supreme Court's pronouncements to the contrary and its reluctance to attribute potential earning capacity to spouses who have been out of the work force have so far prevented full application of the concept. See Teasdel v. Teasdel, 493 So. 2d 1165 (La. 1986); Hegre v. Hegre, 483 So. 2d 920 (La. 1986). The Louisiana State Law Institute has recommended the legislative overruling of the Supreme Court cases. See La. H.B. No. 1139, § 1, art. 107, Reg. Sess., 1987. The recommendation was not acted upon in 1987 and will be proposed again in 1993. 
II

\section{LOUISIANA LAW SINCE 1980}

\section{A. Methods of Restoring Separate Property}

Ownership tracing and reimbursement are the two methods of restoring the separate estate in Louisiana as in all community property states. With the demise in 1980 of the "double declaration" rule, tracing has become more available. ${ }^{12}$ Also, tracing is facilitated by the rule that prohibits implied and oral transmutations of separate to community property. ${ }^{13}$ Even so, Louisiana relies more on reimbursement than on tracing as the method of restoring the separate estate. Whenever known amounts of separate and community funds are used to acquire an asset, Louisiana classifies the asset as community unless the community funds were inconsequential; the separate estate is reimbursed for the funds spent. ${ }^{14}$ Other community property states provide for pro-rata ownership tracing in that situation. ${ }^{15}$ Since reimbursement is Louisiana's primary method of restoring the separate estate, the reimbursement rules are the focus of this article.

\section{B. Situations Occasioning Reimbursement of the Separate Estate}

In Louisiana, spouses may claim reimbursement at the termination of the community regime. ${ }^{16}$ The Civil Code divides all separate claims for reimbursement into two situations: separate property used to pay community obligations, article $2365,{ }^{17}$ and separate property used for community acquisitions or

12. Under the double declaration rule, immovables purchased by the husband with separate funds in his name during the marriage were irrefutably presumed to be community property unless, in the deed of acquisition, he had declared them to be purchased with his separate funds for his separate estate. Absent such recitals, the husband received reimbursement for the separate funds used to acquire the property; he did not have a choice between tracing and reimbursement. See, e.g., Peters v. Klein, 109 So. 349 (La. 1926); Sharp v. Zeller, 34 So. 129 (La. 1902). See also Tullier v. Tullier, 464 So. 2d 278 (La. 1985) (legislative abolition of double declaration rule retroactively applied).

13. LA. CIv. CODE ANN. art. 2343.1 (West 1985).

14. Id. arts. $2338,2341$.

15. See, e.g., Joseph W. MCKNight \& William A. RePPY, JR., TeXas Matrimonial PROPERTY LAw 39 (1983); Harry M. Cross, Community Property: A Comparison of the Systems in Washington and Louisiana, 39 LA. L. REV. 479, 485 (1979). But see California law described infra text accompanying notes 72-82.

16. LA. CIV. CODE ANN. art. 2358 (West 1985). In Louisiana, it is not technically correct to speak of reimbursement from "the community" or from "the community property" because the community regime is not a legal entity, and the claim for reimbursement is really a personal claim against the other spouse. Nevertheless, since reimbursement claims are made and satisfied during the partition of the community patrimony, as a practical matter, the claims are satisfied from the community property (though in one instance, as will be explained, they can exceed the value of the community property). No harm can come from speaking of reimbursement from "the community" so long as one understands that the amount to be reimbursed from "the community" is twice the amount that the Code articles require the other spouse to pay. See Katherine S. SPaHT \& W. Lee Hargrave, Louisiana Civil LAW TREATISE: MATRIMONIAL Regimes \& 7.14, at 283-91 (1989).

17. LA. Civ. CODE ANN. art. 2365 (West Supp. 1992) provides as follows: 
improvements, article $2367 . .^{18}$ However, the use of separate property to pay community obligations does not constitute a distinct situation occasioning reimbursement, as article 2365 might suggest.

A couple's community property exists for two purposes: first, to be consumed by the family in meeting its living expenses, and second, to acquire, improve, or maintain property as investment. Thus, two situations can occasion a claim to reimbursement of the separate estate: (1) when separate property instead of community property has been consumed by the expenses of the marriage and family and (2) when separate property instead of community property has been used or spent to acquire, improve, or maintain community investments. Community obligations may relate either to expenses of the marriage and family or to community investments. In light of the purposes of community property, payment by the separate estate of a community obligation incurred to acquire a community investment should be treated under the rule for reimbursement for acquisitions, while payment of a community obligation, the object of which was to provide for the family, should be reimbursed according to the rule for family expenses. The reimbursement rules differ in important ways depending upon which of the two purposes, expenses of the marriage and family or investments, was involved. ${ }^{19}$

1. Expenses of the Marriage and Family. Any ambiguity in pre-1980 Louisiana law concerning entitlement to reimbursement for expenses of the marriage and family is now resolved in favor of reimbursement. Since such expenses are for

If separate property of a spouse has been used to satisfy a community obligation, the spouse, upon termination of the community property regime, is entitled to reimbursement for one-half of the amount or value that the property had at the time it was used. The liability of a spouse who owes reimbursement is limited to the value of his share in the community after deduction of all community obligations.

Nevertheless, if the community obligation was incurred for the ordinary and customary expenses of the marriage, or for the support, maintenance, and education of children of either spouse in keeping with the economic condition of the community, the spouse is entitled to reimbursement from the other spouse regardless of the value of that spouse's share of the community.

18. Id. art. 2367 (West 1985) provides as follows:

If separate property of a spouse has been used for the acquisition, use, improvement, or benefit of community property, that spouse upon termination of the community is entitled to one-half of the amount or value that the property had at the time it was used. The liability of the spouse who owes reimbursement is limited to the value of his share in the community after deduction of all community obligations.

Buildings, other constructions permanently attached to the ground and plantings made on community property with separate assets of a spouse become community property. Upon termination of the community, the spouse whose assets were used is entitled to one-half of the amount or value that the separate assets had at the time they were used. The liability of the spouse who owes reimbursement is limited to the value of his share in the community after deduction of all community obligations.

19. A similar problem of the overlap of the rule for debts into the area covered by the rule for acquisitions and improvements exists when the community seeks reimbursement under articles 2364 (satisfaction of separate debts) and 2366 (acquisition, use, improvement, or benefit of separate property). See C. Lawrence Orlansky, Note, Termination of the Community, 42 LA. L. REV. 789, 801-03 (1982). 
the common interest of the spouses, they are community obligations as defined by Civil Code article 2360 . If a community obligation is paid with separate property, reimbursement is due under article 2365 . The definition of community obligation includes "an alimentary obligation imposed by law on a spouse."20 Thus, a spouse who owes alimony to an ex-spouse or child support to children of a previous marriage, and who uses his or her separate funds to pay these obligations, is entitled to reimbursement.

Furthermore, when separate funds have been used to pay obligations incurred for the ordinary and customary expenses of the marriage or for the support, maintenance, and education of the children of either spouse, reimbursement is not limited to the value of the community property on hand when recovery is ordered; the other spouse is personally obligated to pay half of the amount so used. $^{21}$ In other words, a spouse is obligated to reimburse ordinary family expenses, whether he or she has a separate estate. In effect, a spouse with no separate property must pay the same amount toward nonextravagant family expenses that exceed the value of the community property out of future (postdissolution) earnings as his or her millionaire spouse.

Had the spouses not contracted to have a community property regime, family expenses would not be shared equally regardless of means. In a separate property regime, in the absence of alternative provisions in the matrimonial agreement, expenses of the marriage are shared in proportion to each spouse's means. ${ }^{22}$ Ironically, a spouse with no separate property may be penalized by living under a community regime with a separately wealthy spouse.

Louisiana's family expenses reimbursement rules may most poignantly affect an unwary stepparent. Because the parent-spouse's alimentary obligation is classified as a community obligation, the stepparent-spouse is, at partition, denied a claim for reimbursement for community funds spent to satisfy the parent-spouse's alimentary obligation. Indirectly, then, the stepparent-spouse must pay for the support of the children of the separately wealthy parent-spouse even though the children may not have been living in the home with the parent and stepparent. $^{23}$ When the amount of child support owed by the parent-spouse is higher, due to the existence of parent-spouse's separate property, than it would have been if based only on community income and assets, the rules operate in an even less equitable manner. ${ }^{24}$

20. LA. CIV. CODE ANN. art. 2362 (West 1985).

21. Id. art. 2365 . To be reimbursable, the expenses must have been in keeping with the economic condition of the community. Id.

22. Id. art. 2373 (West 1985). See Sharpe v. Sharpe, 536 So. 2d 434, 436-38 (La. Ct. App. 1988) (matrimonial agreement to be separate in property said "neither spouse shall have any economic claim upon the other"; held: language precludes reimbursement for living expenses or improvements to other spouse's property).

23. See Janet M. Riley, Stepparent's Responsibility of Support, 44 LA. L. REV. 1753, 1755-61 (1984).

24. In contrast to Louisiana, California forces a spouse who has a separate income to use it to discharge his or her alimentary obligations. CAL. CIV. CODE \$ 5120.150(b) (West Supp. 1992) (community entitled to reimbursement in amount of separate income that was available but not used to pay spouse's child or spousal support obligation). 
Even when neither spouse owes any alimentary obligations, the reimbursement rules operate unfairly where the separate estates of the spouses are unequal. The reimbursement claim of the wealthy spouse for separate funds spent on family expenses can exhaust the other spouse's interest in the community property even though the substantial separate funds permitted the community to live in excess of community means. Unless the separately wealthy spouse is guilty of fraud or bad faith in managing the family expenses, no defense exists to repayment of the wealthy spouse from the community property. $^{25}$

Another of Louisiana's new rules indirectly affects the fairness of allowing the separately wealthy spouse reimbursement for family expenses. Prior to 1980 , the fruits of a spouse's separate property were classified as community property, and the poorer spouse benefitted from these fruits. Even if separate capital was reimbursed, the reimbursement was at least partially offset by the community's receipt of the fruits of the separate property. While the fruits of separate property are still presumptively classified as community property in Louisiana, the 1980 revision gives either spouse the unilateral option to reserve as separate the fruits of his or her separate property. ${ }^{26}$ However, the entitlement to reimbursement does not depend on whether a spouse has exercised this option. When only the wife had the right to reserve the income from her separate property, if she did so, and if she had brought no dowry to the support of the marriage, she was required to contribute to family expenses up to one-half of this income under pre-1980 law. ${ }^{27}$ The law did not let her exercise a potentially selfish option to increase her separate estate without imposing a corresponding obligation for the benefit of the marriage.

Presently, the other spouse may not even know that the separately wealthy spouse has exercised the option. Unlike Wisconsin, Louisiana does not require actual notice to the other spouse. ${ }^{28}$ The other spouse receives only constructive notice through recordation of the declaration reserving the fruits. Few spouses will systematically read the legal notices in the newspaper or periodically check the court records to determine whether the other spouse has reserved the fruits of his or her separate property. A spouse may think the income of the other spouse's separate property is still community, when in fact this income had become separate and, if used on family expenses, will generate a reimbursement claim-a nasty surprise at the termination of the community.

Finally, article 2367 limits a reimbursement claim for separate property used for the acquisition or improvement of community property to the value of

25. See LA. Civ. Code ANN. art. 2354 (West 1985). The claim for loss or damage due to mismanagement could offset the reimbursement claim in whole or in part.

26. Id. art. 2339. The option is criticized in Dian T. Arruebarrena, Rethinking the Classification of Credit Acquisitions Under Louisiana's Community Property Law, 50 LA. L. REV. 973, 991 n.69 (1990). Prior to 1980 only the wife had this right to elect separate classification of the income from separate capital.

27. LA. CIV. CODE art. 2389 (1870).

28. WiS. Stat. ANN. $\$ \S 766.31(4),(7 p), 766.59(2)(b)$ (West Supp. 1991). 
community assets at termination, while article 2365 does not so limit a reimbursement claim for separate property used for family expenses. When a spouse makes both claims, no rule allocates the value of the community assets to one claim or the other if the assets are insufficient to satisfy both. If the value of these assets is allocated first to pay the limited claim, the separate estate will have a better chance of full reimbursement, and the other spouse will have more debt to satisfy personally than if the value is allocated first for the unlimited claim. The Louisiana courts have not addressed this issue, but emphasis on equal responsibility for ordinary expenses could prompt a court to allocate the value of the community property more favorably to the separate estate.

In Guarisco v. Guarisco, ${ }^{29}$ the community had a positive balance net of liabilities to third parties of $\$ 193,240$. The husband's $\$ 611,553$ reimbursement claim not only eliminated any interest the wife had in the community property, but also left her owing the husband $\$ 209,156$. The court stated that the husband's separate funds had been used to retire community debts, purchase a Mercedes auto, and pay community taxes, but did not discuss whether these debts and expenditures were ordinary expenses of the family in keeping with the economic condition of the community. By allowing reimbursement beyond the value of the community assets, the court implied that these expenditures were such ordinary family expenses. The court believed that the "unfair, if not downright inequitable" present law compelled its decision. ${ }^{30}$

The presumption that all obligations incurred during the existence of a community regime are community obligations ${ }^{31}$ makes it difficult for a spouse in a Guarisco situation to defend against a reimbursement claim. The burden appears to be on the spouse defending against the reimbursement claim to prove that a particular obligation incurred during the community regime and paid with separate property was not for the common interest of the spouses, for the interest of the spouse who did not incur the obligation, or for separate property not benefitting the community. ${ }^{32}$ Tort obligations incurred during the community regime are presumptively community obligations, and even intentional wrongs can be community obligations if "perpetrated for the benefit of the community." 33 A spouse who embezzles from his or her employer to finance a family trip will have a reimbursement claim at termination of the community if that spouse uses his or her separate funds to make restitution to the employer.

In sum, Louisiana's present rules on reimbursement of family expenses are simple: Family expenses paid for with separate property, including a spouse's

29. 526 So. 2 d 1126 (La. Ct. App. 1988).

30. Id. at 1132 . The wife was allowed to pay the reimbursement claim in 180 monthly installments of $\$ 1300$ each. See also Maginnis v. Maginnis, 580 So. 2d 709 (La. Ct. App. 1991) (although community insolvent, Mrs. Maginnis owed Mr. Maginnis $\$ 16,884$ for use of his separate funds to pay income taxes and $\$ 12,443$ for ordinary expenses of the marriage).

31. LA. Civ. CODE ANN. art. 2361 (West 1985).

32. See id. art. 2360 (defining community obligations). See also SPAHT \& HARGRAVE, supra note $16, \S 7.12$, at 271 .

33. See LA. Civ. Code ANN. art. 2363 (West Supp. 1992). 
alimentary obligations and even some intentional torts, are reimbursed, sometimes without limitation to the value of the community property. The spouses' respective separate wealth or the willingness of the claimant spouse to contribute the fruits of his or her separate property to the community are irrelevant.

2. Investments. The new rule of article 2367 is also simple: One spouse must reimburse the other for separate property that "has been used for the acquisition, use, improvement, or benefit of community property ...."34 The measure of reimbursement is "the value that the [separate] property had at the time it was used." ${ }^{35}$ Reimbursement is limited to the value of the community property at the time the community is terminated, but the obligation can exhaust the entire community unless offset by damages due to the claimant's fraud or bad faith in the management of the community property.

The devastating effect of an investment reimbursement claim on the other spouse's community interest is illustrated by Cabral v. Cabral. ${ }^{36}$ In 1979 , the husband and wife purchased as community property some land for commercial development. The husband managed the project. He borrowed money to build a commercial structure on the land and rented it to a lessee for a fixed rent for thirty years. The construction of the building cost twice as much as had been estimated, and interest rates on the loans financing the project soared in the early 1980s, with the result that the fixed rent did not cover the interest the couple owed on the loans pertaining to the property. To keep from losing the property, the husband sold some of his separate property and applied the $\$ 566,390$ profit to the accumulating interest on the community project. Then the husband and wife divorced. At the time of the partition of the community property, the balance owed on the commercial property was $\$ 507,629$ and the appraised value, including the lease, was only $\$ 408,000$. Although the husband admitted that he "might have been more attentive in managing the project,"37 the court found a complete absence of fraud or bad faith on the husband's part and granted him reimbursement even though the project was a loss. His reimbursement claim totally consumed the wife's interest, not only in the project on which the separate funds had been spent, but also in the other community assets that had been acquired during the marriage. The court consoled the wife by remarking that the community would have received the profits had the project been successful, and that her debt to her husband was limited to her share of the community property and could not be pursued against her personally since the

\footnotetext{
34. Id. art 2367 (West 1985).

35. Id.

36. 543 So. 2d 952 (La. Ct. App. 1989).

37. Id. at 955 .
} 
separate funds had been spent on an investment rather than on ordinary family expenses. $^{38}$

The result in Cabral is consistent with the new code articles. Once it is proven that separate funds paid a community debt, acquired community property, were used for community property, or benefitted or improved community property, reimbursement is owed for the value the separate property had at the time it was used. In a situation such as Cabral, where the separate funds clearly were used for a community investment, no other fact is relevant to reimbursement under the new articles. ${ }^{39}$

Several additional arguments justify the outcome of Cabral. Unless the mortgages on the property were in rem mortgages, the entirety of the community property (and Mr. Cabral personally, as well as Mrs. Cabral, if she signed the note) was liable to the creditors of the project for repayment of the loan and interest. If Mr. Cabral had not paid the interest with his separate funds, the community property could have been seized by the creditor. What difference does it make to Mrs. Cabral whether she loses her community interest to a creditor or to her spouse? Either way it is lost. To object to this outcome is to object to the basic idea of equal management-that either spouse acting alone may obligate the entirety of the community property. Furthermore, if she concurred in the acquisition of the property and in the loan to improve it, she can hardly object to having to pay for it. She had the right to participate in the management of the project, but instead acquiesced in her husband's sole management. Her right to manage, unexercised by her own choice, entails equal responsibility for the husband's decision to keep the property rather than selling it before so much interest debt accumulated.

Such arguments are persuasive, but others advanced in response are also compelling. First, the spouses' relationship between themselves should not have

38. At least the court of appeal reversed the trial court's denial of the wife's claim for alimony. The trial court had refused to award her alimony after finding that she was capable of earning $\$ 600$ per month and had separate property consisting of jewelry, silver, and furs worth $\$ 120,000$ plus naked ownership of $\$ 50,000$. The court of appeal awarded her $\$ 1750$ per month alimony. She was 54 years old, had two years of college, and had not held a job for thirty years. In connection with the alimony claim, it was noted that the husband's income now included a small positive cash flow from the "loser" community investment that now belonged to him, together with the rest of the community property, in satisfaction of his reimbursement claim.

39. LA. CIV. CODE ANN. art. 2367 (West 1985). Proof that the target of the separate funds was indeed a community debt or asset is still a prerequisite for reimbursement under the new articles. In Starr v. Starr, 557 So. 2d 1026 (La. Ct. App. 1990), Mr. Starr claimed reimbursement for having used separate funds to pay the rent for a community enterprise. In defense to his reimbursement claim, Mrs. Starr asserted she had donated her interest in the community enterprise to Mr. Starr, and hence the rent he paid with his separate funds was for his separate enterprise. The court held that her alleged oral donation of her interest in the community enterprise lacked the proper form for a donation and was null. Mr. Starr received reimbursement. See also Guttuso v. Guttuso, 540 So. 2d 1293 (La. Ct. App. 1989) (Mrs. Guttuso denied reimbursement for separate funds paying off second mortgage on separate property because there was no proof that borrowed proceeds were used for community benefit.), and Davezac v. Davezac, 483 So. 2d 1197 (La. Ct. App. 1986) (Mr. Davezac denied reimbursement for separate funds paying his business expenses, which he alleged redounded to community's benefit; some expenses were for his personal benefit and no accurate categorization could be made.). 
to parallel the spouses' relationship to their creditors. This point is implicitly recognized in Louisiana community property law when a reimbursement between spouses is treated as an interest-free loan, ${ }^{40}$ while a debt to be repaid to a creditor will bear interest. The creditor has entered into a legal relationship with a spouse solely for the purpose of making money, but a marriage is not entered into for profit. Although both spouses risk losing everything to the creditor when they speculate, the disparity in their separate wealth makes the risk much greater for the spouse who has only community property. While the law does not require creditors to show mercy toward debtors, a less strident result is desirable when the parties are married.

The fact that Mrs. Cabral consented to the purchase of the speculative community investment is intuitively relevant to the objective fairness of allowing Mr. Cabral reimbursement. Consent is not, however, relevant under either code article governing reimbursement to the separate estate. Thus, Mr. Cabral would have been entitled to reimbursement even if he had made the speculative investment without his wife's consent or knowledge. The consent of both spouses is not required in Louisiana to acquire community property. ${ }^{41}$ Although it is unlikely that large real estate projects would be financed without a mortgage, which would require both spouses' consent, ${ }^{42}$ other risky community investments, such as purchase of stock on margin, could well be made by one spouse acting alone. Even so, the lack of a consent requirement need not have made consent irrelevant in connection with a reimbursement claim. ${ }^{43}$

Furthermore, a spouse who makes a leveraged investment with separate funds might try later to shift the remaining risk to the community without the other spouse's consent by stipulating that the property would henceforth be part of the community pursuant to article 2343.1 . $^{44}$ Once a separate-to-community transmutation is effected, the payments that remain to be made after the transmutation would be reimbursable if made with separate property. Although an authentic act is required by article 2343.1 for a gratuitous transmutation such as this, there is no explicit requirement of acceptance by the other spouse. Article 2343.1 may imply a requirement of acceptance by the transferee-spouse before the property and accompanying debt can be considered community when it refers to a "transfer ... to the other spouse." ${ }^{\text {" } 55}$ In the case of transmutation

40. See LA. CIV. CODE ANN. art. $2364 \mathrm{cmt}$. d (West 1985) (characterizing the "amount used" measure of reimbursement as an "interest-free loan").

41. Id. art. 2347. In some states, purchase of community realty is a joint management transaction. See generally Oldham, supra note 2.

42. LA. Civ. CODE ANN. art. 2347.

43. See Clarence J. Morrow, Matrimonial Property Law in Louisiana, 34 TUL. L. REV. 3, 48 (1959).

44. LA. CIv. CODE ANN. art. 2343.1 states the following:

The transfer by a spouse to the other spouse of a thing forming part of his separate property, with the stipulation that it shall be part of the community, transforms the thing into community property. As to both movables and immovables, a transfer by onerous title must be made in writing and a transfer by gratuitous title must be made by authentic act.

45. Acceptance of donations is required under the general law, LA. CIV. CODE ANN. arts. 1540-50 (West 1985 \& Supp. 1992), but article 2343.1 expressly governs gratuitous attempts to change separate 
by formal stipulation, the courts should infer an acceptance requirement whenever the transferor claims that the property became community. The opposite result would be unjust. In the case of the initial community investment made without consent, however, the spouse against whom reimbursement is claimed has no defense other than to seek damages for fraud or bad faith in the management of the community property.

Even if the spouse against whom reimbursement is claimed consented to the initial investment, that consent may be insufficient to justify reimbursement for all management decisions made thereafter by the separately wealthy spouse managing the investment independently. The separate wealth of the managing spouse may enable that spouse to make management decisions, such as extending a community risk, that the managing spouse would have been unable to make without the other spouse's consent if the only assets available for investment had been community. For example, Mr. Cabral did not need to consult Mrs. Cabral before selling his separate property and applying it to the interest on the community loan. Without separate property, he might have had to consult her on liquidating or encumbering other community assets. ${ }^{46}$ She then would have had notice that the investment had become dubious and could have exercised her management rights as she saw fit. Separate wealth, in effect, allows the spouse who owns it to bypass the other spouse in the management of the community property.

The legal authority of a spouse to prevent or alter the management decision of the separately wealthy spouse is also relevant to the fairness of allowing reimbursement against the less wealthy spouse. Even if a spouse knows that the separately wealthy spouse is about to use his or her separate funds for a community investment, the management rules seldom provide a veto to this action. ${ }^{47}$ For example, if the separately wealthy spouse is managing a leveraged community stock portfolio and all of the stock is registered in his or her name, that spouse is the exclusive manager of the stock under the management rules

property into community property, and, as the more specific law, it would seem to preempt the general law of donations. That is, whether acceptance is a part of the transmutation will be decided by construing only the language of article 2343.1 .

46. The husband would have had to involve the wife to encumber or alienate community immovables titled in either or both names or movables titled in both names. Id. art. 2347. Although the wife's community earnings and community income from the wife's separate property are obligated by the husband's signature alone, Id. art. 2345 (West 1985), as a practical matter, if the creditor were relying on the wife's community earnings and income as the basis for the decision to make or extend a loan, the creditor would probably want the wife's signature or guaranty to obligate her personally so that she would be less likely to dissipate the community income she controls. Since her signature would obligate her separate property, the creditor would be protected in the event she elected to make the future income from her separate property separate under LA. CIV. CODE ANN. article 2339.

47. The only effective way to stop the extension of the investment would be to sell the investment before the spouse who desires to extend it can liquidate or borrow on his or her separate property to extend the investment. Where the community investment is immovable property titled in either or both names, or movable property titled in both names, the spouse who objects to the extension cannot sell without the concurrence of the other spouse. See id. art. 2347. If the investment is a movable titled in the name of the spouse who wishes to extend the investment, the objecting spouse has no authority to sell. Id. art. 2351 . 
and the other spouse is legally powerless to affect the decisions with respect to the portfolio. Reimbursement should not be justifiable on the ground that the spouse against whom reimbursement is claimed was an equal manager of the community when the exception of sole and exclusive management, not the general rule of equal management, applied to the investment for which reimbursement is sought.

Finally, the community should be protected from loss due to management decisions made through use of separate property but nevertheless reap gain from such decisions because, under a community regime, the spouses' common endeavor should be more important than a spouse's separate endeavor. ${ }^{48}$ The pro-community preference is already expressed in the community regime by the presumption that all property possessed during the marriage is presumed to be community. ${ }^{49}$ The Louisiana Supreme Court has stated that this preference is based on such important social policy that the presumption can be rebutted only by clear and convincing evidence. ${ }^{50}$ The general rule that classifies the fruits of separate property as community also evidences this preference. ${ }^{51}$ Spouses who do not wish to have a common endeavor with respect to their property are free to adopt a regime of separation of property by matrimonial agreement. But if they live under the legal regime of community, they are entitled to and should expect rules that favor the common endeavor.

Louisiana's rules permitting reimbursement to the separate estate thus neglect several factors bearing on the fairness of reimbursement: disparity in the risk run by spouses of unequal wealth, consent, legal control and effective control of management, and the preference implicit in the community regime for the common endeavor over the separate endeavor. The next part will review prior Louisiana law and the law of other jurisdictions to determine whether those regimes consider these factors.

\section{III}

\section{CONTINUING BENEFIT-LOUISIANA's PRE-1980 RULE}

It may seem odd to consult the pre-1980 Louisiana law, which was based upon a sexist management scheme now thoroughly discredited. However, the rules may elucidate certain aspects of the relationship between the spouses under sex-neutral management rules. Rules developed for a system where one spouse had sole and exclusive management are not irrelevant to an equal management

48. See Susan Prager, The Persistence of Separate Property Concepts in California's Community Property System, 1849-1975, 24 UCLA L. REV. 1, 7 (1976)(“[A] community property law makes the assumption that common ownership is highly desirable, preferring and encouraging community, instead of separate, ownership.").

49. LA. Civ. CoDe ANN. art. 2340 (West 1985).

50. Succession of Lyons, 452 So. 2d 1161 (La. 1984) (dictum). The Civil Code, however, does not suggest a standard of proof higher than preponderance of the evidence. See LA. CIV. CODE ANN. art. 2340 .

51. LA. Civ. CODE ANN. art. 2339. 
system. Devices employed to protect the community against single-spouse management might be even more useful when there are two independent managers. Furthermore, though the present general rule gives the spouses equal legal authority to manage, it does not necessarily follow that reimbursement rules could not consider unequal management in fact. Some reimbursement claims even involve situations where the spouse claiming reimbursement was legally the exclusive manager under one of the exceptions to equal management.

Under the old law, the rules concerning restoration of the separate estate at termination of the community were created almost entirely through judicial opinions. Neither tracing nor reimbursement found comprehensive expression in the Civil Code. ${ }^{52}$ Unconstrained by code articles mandating reimbursement, the courts made rules intended more to protect the nonmanaging spouse's community interest than to restore the managing spouse's separate estate.

A marriage in which the managing spouse had separate property presented first the problem of manipulation. A managing spouse who controlled both his or her own separate funds and community funds, and who also controlled the obligations satisfiable out of community property, was in a position to manipulate a profit or loss between the two estates for any acquisition, improvement, or expenditure. The managing spouse might, for example, have used all of his or her separate funds to finance unsuccessful investments he or she planned to claim as separately owned if successful. Later, by claiming he or she had used the separate funds for community purposes (that is, seeking a community gain), the managing spouse could seek reimbursement from the community, indirectly recouping personal losses from the community. To protect the nonmanaging spouse from this kind of manipulation, the law refused the managing spouse a presumption that he or she had used the separate property for the benefit of the community; instead, when the managing spouse claimed reimbursement of his or her separate funds, the law required the managing spouse to prove not only the existence of the separate funds, but also that they had been used for the benefit of the community. ${ }^{53}$

52. Although the jurisprudence permitted ownership tracing of separate funds in some instances, it was not until an amendment in 1912 to LA. CIV. CODE art. 2334 (1870) that the code expressly recognized that acquisitions with separate funds were separate property. See Robert A. Pascal, Work of the Appellate Courts -- 1968-1969, 30 LA. L. REv. 219, 223-25 (1969). The Louisiana Civil Code of 1870 never contained any articles concerning reimbursement of the husband's separate estate, but the jurisprudence recognized the right. See LA. CIV. CODE ANN. arts. $2365 \mathrm{cmt}$. c, $2366 \mathrm{cmt}$. c.

LA. CIV. CODE art. 2391 (1870) gave the wife the right to restitution of her paraphernal property (that is, nondotal separate property), and article 2403 (1870) provided a rule for the charging of antenuptial debts to separate property and debts contracted during the marriage to community property. Both of the articles were repealed. Those were the only articles aside from the articles on dowry that were relevant to separate claims to reimbursement. The code was equally cryptic concerning community claims to reimbursement. In addition to article 2403 concerning debts, there was only article 2408 , which gave the community the right to claim the value of the increase in separate property due to the common labor of the spouses. The old code articles were never satisfactory in any of these areas of law. See Robert A. Pascal, Work of the Appellate Courts -- 1975-1976: Matrimonial Regimes, 37 LA. L. REV. 358, 365 (1977) [hereinafter Matrimonial Regimes].

53. Huie, supra note 1 , at $166-67$. 
Originally, the requirement placed on the manager to prove that a community benefit resulted from the expenditure of the manager's separate funds was addressed to the manipulation problem. It was intended to make the manager show that his or her separate funds went to a community, rather than a separate, purpose. But a line of decisions went further, holding that past benefit to the community was not enough to justify reimbursement; the benefit to the community must still exist at termination of the community. ${ }^{54}$

Under this "continuing benefit rule," the managing spouse had an almost insurmountable burden of persuasion to win reimbursement when he or she had commingled separate funds with community funds, or when separate funds had been spent on family living expenses from which no particular benefit existed at termination. ${ }^{55}$ Without evidence linking separate funds directly to a particular community asset or benefit still in existence at termination, the reimbursement claim would be rejected. Purporting to apply this rule, one appellate court allowed a reimbursement claim to succeed where the court was completely convinced that the manager was successful in business, suffered no business reversals, and was never in debt, and the community investments had increased beyond the amount by which they would have grown without the investment of separate funds. ${ }^{56}$

The line of cases requiring that the benefit to the community continue until termination addressed not only the manipulation question of where the husband's separate funds had gone, but also served as a final judicial check on the performance of the managing spouse. That spouse's entitlement to reimbursement depended upon whether the separate funds had produced any lasting good for the community in the form of property to be divided at termination. Thus, in a case where the husband's separate funds had paid the note on the community Chevrolet, which the spouses no longer owned at dissolution, no reimbursement was allowed. ${ }^{57}$ The Louisiana Supreme Court sometimes defined the continuing benefit requirement as an "enhancement of the community at its dissolution." ${ }^{8}$ The requirement had the effect of subordinat-

54. Id. at 176-89. See also Succession of Provost, 181 So. 802 (La. 1938); Succession of Ferguson, 84 So. 338 (La. 1920); Munchow v. Munchow, 67 So. 819 (La. 1915); Heirs of Gee v. Thompson, 6 So. 548 (La. 1889) (seminal cases for the continuing benefit requirement).

55. Succession of Turgeau, 58 So. 497 (La. 1912) (denying wife reimbursement for separate funds spent on living expenses when husband was ill and impecunious). See also Succession of Dutin, 149 So. 363 (La. 1933). But see Mier v. Troxler, 235 So. 2d 170 (La. Ct. App. 1970); Heirs of Gee v. Thompson, 6 So. 548 (La. 1889) (denying the husband reimbursement for a pleasure trip taken by both spouses).

56. Succession of Videau, 197 So. 2d 655 (La. Ct. App. 1967).

57. Gouaux v. Gouaux, 211 So. 2d 97, 102-03 (La. Ct. App. 1968). No evidence of a trade-in was presented. Presumably the Chevrolet was wrecked or sold and its proceeds consumed so as not to be traceable to a benefit existing at dissolution.

58. Abunza v. Olivier, 88 So. 2d 815, 821 (La. 1956). See also Succession of Russo, 246 So. 2d 26, 30 (La. Ct. App. 1971) (holding that funds must inure to the benefit of community); Paxton v. Bramlette, 228 So. 2d 161, 166 (La. Ct. App. 1969) (entitling husband to restitution only where his separate funds have enhanced the value of community); Broyles v. Broyles, 215 So. 2d 526, 528 (La. Ct. App. 1968) (requiring husband to demonstrate that his separate funds increased the value of community). 
ing the goal of restoring the manager's separate property to the goal of protecting the community property until termination.

The "enhancement at dissolution" rule was not without its critics. Professor Huie thought it made a reimbursement claim too difficult to prove; it often relegated the husband to ownership-tracing as the only means of restoring his separate capital. ${ }^{59} \mathrm{He}$ also criticized the rule because it allocated the risk of capital loss on a community investment to the separate estate. He reasoned that capital loss should fall on the estate that was sought to be improved or benefitted. ${ }^{60}$ According to Huie, family living expenses should be borne by the community, and the separate estate should be reimbursed for having enriched the community by paying them. ${ }^{61}$ While he acknowledged that the motive for the enhancement-at-dissolution rule was the courts' commendable desire to protect the nonmanaging spouse, he objected to "judicial review" of the manager's actions, pointing out that the requirement of continued enhancement was inconsistent with the manager's broad power to manage the community. Since the manager was liable only for losses to community property due to his fraud, his reimbursement from the community should be denied only in cases of fraud. $^{62}$ Huie believed that maintaining reimbursement as a viable way to restore separate capital was more important than having an additional legal tool to control mismanagement. ${ }^{63}$ Despite Huie's criticism, the decisions rendered after publication of his articles persisted in holding that for the manager successfully to claim reimbursement, the benefit to the community had to exist at termination. ${ }^{64}$

59. Huie, supra note 1 , at 144 .

60. Id. at $188-89$.

61. Id. at 159. Arguably, reimbursement of living expenses, a kind of debt contracted during the marriage, was mandated by Louisiana Civil Code article 2403 of 1870.

62. See Huie, supra note 1 , at 197-205. Prior to 1980 , the husband was liable, with respect to his management, to the wife or her heirs only for fraudulently disposing of the community property. He could make donations of individual community movables without his wife's consent. See LA. CIV. CODE art. 2404 (1870). Huie did think that the law should have been amended to require the wife's consent to donations, Huie, supra note 1 , at 210 , and suggested broadening the remedy of separation of property if protection for the wife in cases of the husband's extravagance was desired, id. at 200.

63. Huie, supra note 1, at 199-200, 204 (arguing that reimbursement should be allowed even for extravagant expenses by the husband even if the wife's interest in the community would be extinguished). Huie suggested broadening the separation of property remedy as a preferable way to protect the wife. See LA. Civ. CoDE art. 2425 (1870), now LA. Civ. CodE ANN. art 2374 (West 1985).

64. See Abunza, 88 So. 2d 815; Messersmith v. Messersmith, 86 So. 2d 169 (La. 1956); Compton v. Compton, 371 So. $2 d 313$ (La. Ct. App. 1979); Lane v. Lane, 375 So. 2d 660, 674-75 (La. Ct. App. 1978); Gouaux, 211 So. 2d 97; Succession of Videau, 197 So. 2d 655; Pennison v. Pennison, 157 So. $2 d 628$ (La. Ct. App. 1963) (alternate holding denied the husband's claim for reimbursement for community's use of his separate home because such use involved no enhancement of the community existing at dissolution). The enhancement at dissolution rule appeared in dicta in Slater v. Culpepper, 99 So. $2 \mathrm{~d} 348$, 360 (La. 1957), Turner v. Turner, 533 So. 2d 31, 33 (La. Ct. App. 1988) (pre-1980 law), and Downs v. Downs, 410 So. 2d 793 (La. Ct. App. 1982) (same). Paxton, 228 So. 2d at 166, stated that the husband must show "that his funds have been employed to enhance the value of the community property," and cited the above line of cases as authority. Succession of Russo imposed the enhancement standard for reimbursement on a wife by denying her reimbursement for the separate funds she deposited in a community account because the benefit to the community was not of "such a nature as to give the community a strong and substantial economic advantage." 246 So. $2 d$ at 30. 
Finally, the pre-1980 law on the measure of reimbursement tended to favor the community over full restoration of the separate estate. When separate funds were used to acquire an asset that was classified as community property because of the rules forbidding tracing, the spouse was reimbursed the amount spent. ${ }^{65}$ But when separate funds were used to improve a community asset, the courts were split, some awarding the amount spent, others limiting reimbursement to the amount by which the community property had been enhanced at dissolution. ${ }^{66}$ Although there were few cases involving the measure of reimbursement to the separate estate in improvement situations, it seems to have been assumed by the bar that the numerous cases applying the enhancement limitation to community claims for reimbursement applied equally to separate claims for reimbursement. ${ }^{67}$ Indeed, the drafters of the 1980 changes in the law stated that under the old law, when reimbursement was sought by the separate estate because the community property had increased in value, the measure of reimbursement was "enhanced value." ${ }^{68}$ Professor Huie protested that the rule limiting reimbursement to enhanced value at dissolution, even though the amount spent was greater, defeated restoration of the separate estate. $\mathrm{He}$ argued that the community, as owner of the improved property, should have the risk of loss as well as the opportunity for gain. As beneficiary of the fruits and revenues of the separate property, the community also should compensate the separate estate for both depreciation due to use and depreciation due to market forces. The community should thus repay the separate estate the amount spent without regard to enhanced value existing at dissolution. ${ }^{69}$ Again, his arguments seem not to have influenced courts. The courts probably believed it unfair to give primacy to the restoration of the managing spouse's separate estate.

To summarize, the law on restoration of the separate estate prior to 1980 , almost entirely judge-made, was fashioned to do justice to the nonmanaging spouse by protecting the community more than to restore the separate estate of the managing spouse. The courts accomplished this by making it difficult for the managing spouse to prove entitlement to reimbursement unless the community still prospered at termination, and by limiting the amount of reimbursement in improvements cases to the amount of enhancement existing at dissolution (not to exceed amount spent). Critics argued that this state of the law was inconsistent with a ganancial system, inadequately serving the goal of separate estate restoration. If the goal of restoring the separate estate had been accepted as paramount, the argument would have been compelling. But the courts denied

65. Huie, supra note 1 , at 212 .

66. Id. at 212-14. See Pascal, Matrimonial Regimes, supra note 52, at $372-73$ (stating that the proper measure of restitution to the separate estate under equitable principles was the value of the improvement as it stood at dissolution of the regime, not the amount spent on the improvement).

67. Huie, supra note 1 , at 214 .

68. LA. Civ. CODE ANN. art. $2365 \mathrm{cmt}$. c (West 1985).

69. Huie, supra note 1, at 212-17. He also thought that use of the enhancement measure would involve "valuation problems of considerable difficulty." Id. at 217. 
the primacy of this goal and persisted in protecting the interest of the nonmanaging spouse in the community property.

The 1980 code articles did not codify the jurisprudential rule that the benefit to the community must still exist at termination of the community regime in order for the separate estate to be reimbursed. Yet some cases decided under the 1980 code articles refer to community benefit as the key to reimbursement as if the revisions included such a provision. In Succession of Davis, ${ }^{70}$ even though the trial court found that the commingled funds were used by the community, the appellate court did not allow reimbursement. The court of appeal held: "In order to claim reimbursement [successfully] for separate funds allegedly expended in satisfaction of community obligations or to benefit the community, a spouse . . . must show that the funds were actually used to benefit the community." 71 Some of these cases even cite pre-1980 jurisprudence as authority. In Succession of Blythe, ${ }^{72}$ the daughter of the deceased husband claimed reimbursement totaling $\$ 168,468$ from a community valued at $\$ 148,900$. She presented evidence that her father had derived the separate funds from the sale of his separate property, and that since the community earnings were only $\$ 6000$ a year, his separate property had to have benefited the community either by buying the community assets or by paying the living expenses. Citing cases decided under pre-1980 law requiring "compelling proof that a strong and substantial economic advantage inured to the community," the court denied the daughter's claim. ${ }^{73}$ Since it is clear under the 1980 civil code articles that the separate estate may be reimbursed for living expenses, and that "use" of separate funds on community property independent of "benefit" will entitle the separate estate to reimbursement, the court should have granted the daughter's claim if it believed her evidence (and no evidence was offered indicating separate use of

70. 536 So. $2 d 498$ (La. Ct. App. 1988).

71. Id. at 501-02. The court of appeal remanded for further proof of community benefit. Contrary to the cases emphasizing benefit, a case involving livestock applied a less stringent reimbursement rule of pre-1980 law for livestock: unless the entire commingled herd has died, the spouse who contributed separate livestock to a commingled herd is entitled to reimbursement in kind of the original number of separate animals without showing what happened to each separately owned animal. Succession of Erbelding, 509 So. 2d 568, 571 (La. Ct. App. 1987). Thus, if the husband uses his separate funds to buy five bulls at $\$ 5000$ each for the community herd, no further proof is needed to entitle him to reimbursement in kind of animals worth $\$ 25,000$ (provided the entire herd has not died). If, instead, he had bought five blocks of common stock for $\$ 5000$ each and added them to a community portfolio, he would be required to show that there was no loss on each of these investments.

72. 496 So. 2d 1180 (La. Ct. App. 1986) (citing Succession of Vice, 385 So. 2d 554 (La. Ct. App. 1980), Succession of Videau, 197 So. 2d 655, and Succession of Russo, 246 So. 2d 26).

73. 496 So. $2 \mathrm{~d}$ at 1183 . For additional cases (decided after the 1980 codal revisions) stressing proof of community benefit and citing old jurisprudence, see Landwehr v. Landwehr, 547 So. 2d 752 (La. Ct. App. 1989); Kaplan v. Kaplan, 522 So. 2d 1344 (La. Ct. App. 1988); Patterson v. Patterson, 417 So. 2d 419 (La. Ct. App. 1982). Possibly consistent with these cases is the cryptic holding in Mexic v. Mexic, 577 So. 2d 1046 (La. Ct. App. 1991), which denied Mr. Mexic reimbursement for (presumably) separate funds spent on (presumably) community property in an attempt to avoid an investment tax recapture. The court simply said that Mr. Mexic had no obligation to make the payment and thus was not entitled to reimbursement. Id. at 1052. 
the separate property), rather than insisting on proof of "strong and substantial economic advantage" to the community.

As was true before 1980, the courts applying the 1980 code articles find proof of sufficient economic advantage to the community when the reimbursement claim does not obliterate the community property. Thus, in Ziegler v. Ziegler, ${ }^{74}$ the court found compelling proof of community benefit and allowed the husband's reimbursement claim for $\$ 53,240$. Since community earnings in the relevant years had been meager in comparison to the husband's separate funds, the court accepted the inference that his separate funds had to have been spent on the community mortgage and the construction of a community house. In Ziegler, a total community of $\$ 1,376,871$ existed for the spouses to divide; the community had prospered overall, and payment of the reimbursement claim would still have left a considerable community interest for the other spouse.

What distinguishes Davis, Blythe, and Ziegler, with their emphasis on benefit, from Cabral and Guarisco is the fact that funds were commingled or not directly traceable in the former group of cases, whereas in the latter cases, separate funds were proven to have been spent on a particular community project or debt. The 1980 code articles, however, do not prohibit reimbursement where funds are commingled. As long as it is proved that the commingled funds were spent for community investments or family expenses, any separate funds within the commingled funds spent are apparently reimbursable under the 1980 articles. ${ }^{75}$ The purposes served by the courts' references to community benefit or strong and substantial economic advantage are to allow for proof that the commingled funds (and the separate funds within) may have been lost on bad investments, and to deny reimbursement in such cases. This interpretation of the 1980

74. 537 So. 2d 1207 (La. Ct. App. 1989).

75. See Young v. Young, 549 So. 2d 437 (La. Ct. App. 1989). In Young, a permanently disabled husband and his wife lived off his Social Security disability benefits and her $\$ 800$ to $\$ 1000$ per month wages. Mr. Young purchased real estate and a tractor from an account containing his considerable separate property personal injury recovery, and meager community funds. The court held that the purchases were community, but that Mr. Young was entitled to reimbursement of the purchase price. The purchases had been made with cash, and there was not enough community income at the time of each purchase to have produced all the cash. The record showed it was "virtually impossible for these community advantages to be gained without [Mr. Young's] separate funds." Id. at 441 . See also Thibodaux v. Thibodaux, 577 So. 2d 758 (La. Ct. App. 1991) (Mr. Thibodaux denied reimbursement where he commingled proceeds of sale of separate property with community funds, but any benefit to community from commingling offset community claim for reimbursement for mortgage payments and improvements made on the property prior to sale).

In the following cases, commingling prevented tracing, but the argument that the commingled funds (including the separate funds within) were spent in such a way as to entitle the spouse whose separate funds were used to reimbursement was not mentioned: Hinckley v. Hinckley, 583 So. $2 \mathrm{~d} 125$ (La. Ct. App. 1991) (reimbursement allowed for separate property traced to community immovable, but reimbursement issue not raised concerning commingled stock portfolio); Cason v. Cason, 564 So. $2 \mathrm{~d} 808$ (La. Ct. App. 1990) (commingled personal injury award); Martinez v. Martinez, 556 So. 2d 668 (La. Ct. App 1990) (commingled stock account); Breaux v. Breaux, 555 So. 2d 1001 (La. Ct. App. 1990) (Mr. Breaux failed to prove original amount of separate stock in one company, but court held his separate shares in whatever amount were inextricably commingled with community shares in that company; therefore, all shares were community). 
articles, though commendable for the protection it affords the community, calls for proof of facts beyond those required by the code articles for reimbursement.

\section{NO REIMBURSEMENT FOR FAMILY EXPENSES; LIMITED REIMBURSEMENT} FOR INVESTMENTS: CALIFORNIA LAW

A comparison of Louisiana's rules on restoration of the separate estate to those of California is helpful for several reasons. California, like Louisiana, requires an equal division of the community property at termination of the regime, and does not permit the court to divide separate property. ${ }^{76}$ Since the courts, at least in theory, have no discretion to do justice by means of an unequal division of community property or by awarding one spouse some of the separate property of the other, both states should have rules on restoration of the separate estate carefully thought out to insure fairness. California, like Louisiana, codified some of its rules concerning restoration of separate property in the 1980s. Both states have equal management as the general rule of management. Of the differences between the community property regimes of the two states, the most important is the following: In California, the fruits and revenues of separate property are separate, while in Louisiana they are community unless the spouse who owns the separate property formally declares the fruits to be separate.

Prior to the 1980s, California's rules were, as were Louisiana's, largely judge-made. But the California courts had in one respect gone further than Louisiana in protecting the community property from claims for restoration of the separate estate. In the landmark 1966 California case of See v. See, ${ }^{77}$ the husband, who sought to trace his separate funds to assets remaining at dissolution, argued that since family expenses during the marriage had exceeded community income during the marriage, all the community income should be imputed to those expenses; consequently, he argued, the remaining assets should be attributed to his separate funds. The California Supreme Court rejected the husband's theory, known as tracing by "total recapitulation," because the theory implicitly reimbursed the husband for any separate funds that were spent on living expenses. Such reimbursement was contrary to California's rule that a spouse who uses separate funds for living expenses has made a gift of those funds and cannot claim reimbursement absent an agreement. One justification by the court for the no-reimbursement rule was that the use of separate property enabled the family to maintain a standard of living beyond the community means, and thus reimbursement would be unfair when claimed by the manager

76. CAL. Civ. Code $\S 4800$ (West Supp. 1992); LA. Civ. Code ANN. art. 2336 (West 1985); LA. REV. STAT. ANN. \& 2801 (West 1991).

77. 415 P.2d 776 (Cal. 1966). 
of the community. ${ }^{78}$ The change to equal management in California has not dislodged the no-reimbursement rule. ${ }^{79}$

In Marriage of Lucas, ${ }^{80}$ the California Supreme Court extended the no-reimbursement rule from the "total recapitulation" context to the context of an investment acquisition. It refused to allow a wife who had used her separate funds as the downpayment on immovable property during marriage, title to which was taken in both names, either to trace or to claim reimbursement. The court said that while the spouses were living together, "unless an agreement between the parties specifies that the contributing party be reimbursed, a party who utilizes his separate property for community purposes intends a gift to the community." 81 The California Supreme Court later stated that it regarded this rule as having been well established for more than twenty years. ${ }^{82}$

After the Lucas decision, the legislature enacted civil code section 4800.2 as an exception to the no-reimbursement rule. ${ }^{83}$ Although it allows reimbursement in investment cases, it contains safeguards for the community. Section 4800.2 , applicable to the division of community property at divorce or legal separation, ${ }^{84}$ provides that a spouse shall be reimbursed for separate contributions to the acquisition of community property unless he or she has waived the right in

78. See v. See did permit a limited use of the inference that community income was spent on family expenses: to show that no community funds were available at a particular point in time. Id. at 780 . Even this limited inference is criticized in Ralph Ehrenpries, Comment, Community Property: Commingled Accounts and the Family-Expenses Presumption, 19 STAN. L. REV. 661 (1967). In a case where all income during the marriage is separate, California permits the spouse who used separate income to pay family expenses to offset this amount against the community's claim for the gain on his other separate property due to his or her labor. Beam v. Bank of America, 490 P.2d 257 (Cal. 1971).

79. See Marriage of Epstein, 592 P.2d 1165 (Cal. 1979). The laws of the various community property states differ concerning reimbursement of family expenses. See WILLIAM A. REPPY \& CYNTHIA SAMUEL, COMMUNITY PROPERTY IN THE UNITED STATES 10-7 (3d ed. 1991) (noting that Idaho and Arizona have used total recapitulation accounting, which presumes reimbursement for living expenses; that Texas cases are inconsistent on whether there can be reimbursement for living expenses, and that recent New Mexico cases deny such reimbursement). New Mexico, like California and Louisiana, requires an equal division of the community property. Michelson v. Michelson, 520 P.2d 263 (N.M. 1974). Thus, of the three equal division states, two do not allow reimbursement for family expenses.

80. 614 P. 2 d 285 (Cal. 1980).

81. Id. at 289 (quoting Marriage of Epstein, 592 P.2d at 1169). The property in Lucas was a joint tenancy, but was presumed to be community under a special California rule pertaining to divorce. See CAL. Civ. CODE $\$ 4800.1$ (West Supp. 1993).

82. Marriage of Fabian, 715 P. 2d 253, 256 (Cal. 1986). Marriage of Epstein had created an exception to the no-reimbursement rule where expenditures of separate funds on former community property were made after the spouses were no longer living together. 592 P.2d at 1169 . Nevertheless, under the Epstein exception, reimbursement was not always for the amount paid. The court took into account whether the expenditure enhanced the property and whether reimbursement for the amount paid would eliminate the community's equity in the property. Marriage of Reilley, $242 \mathrm{Cal}$. Rptr. 302 (Ct. App. 1987).

83. Act to Amend the Civil Code relating to property ch. 342, \& 1, 1983 Cal. Stat. 1538.

84. The Lucas rule of no tracing and no reimbursement for separate funds that increase the equity in a community investment is applicable when the community is dissolved by the death of a spouse. There seems to be no reason why the reimbursement rule of California Civil Code $\$ 4800.2$ should not apply to dissolution at death, as well as divorce and judicial separation. Since in these kinds of dissolution equal division of the community is required, what purpose is served by having different reimbursement rules depending on which event dissolves the community regime? 
writing. Contributions include downpayments, payments for improvements, and payments that reduce the principal of a loan used to finance the purchase or improvement of the community property. The protection for the community lies in section 4800.2's measure of reimbursement: the amount reimbursed shall be without interest or adjustment for change in monetary values, and shall not exceed the net value of the property at the time of the division. Furthermore, reimbursable separate contributions do not include payments of interest on the loan used to finance the purchase or improvement, or payments made for maintenance, insurance, or taxes on the property. ${ }^{85}$

Under section 4800.2, the wife in the Louisiana Cabral case would have fared much better. ${ }^{86}$ Her husband's reimbursement claim could not have included the interest payments he allowed to accumulate, nor could his reimbursement claim have extended beyond the net value of the particular property that the payments were used to acquire or improve. The rest of the community property would have been preserved for the division. Had the community in Cabral terminated at death, under California's Lucas decision Mr. Cabral's heirs would have been denied any reimbursement. Had Louisiana's Guarisco case been decided under See v. See, living expenses would not have been reimbursable at all, and there might have been community property left to divide.

Even if California's reimbursement rules did not effectively protect the community, the duties California imposes on a spouse in managing the community may perform a similar function. Civil Code section 5125, as amended in 1991, imposes the "general rules governing fiduciary relationships which control the actions of persons having relationships of personal confidence" upon a spouse who is managing community property. ${ }^{87}$ This statute places a duty of "the highest good faith and fair dealing on each spouse," and admonishes that "neither shall take unfair advantage of the other." conduct required of a spouse would enable a court to protect the community from any manipulation and speculation, and possibly also serious negligence of the spouse claiming reimbursement of his or her separate property. ${ }^{89}$ The

85. California Civil Code $\S \mathbf{4 8 0 0 . 2}$ has been held not to apply when after separation a spouse uses his salary, now separate under California Civil Code $\$ 5118$, to pay a mortgage debt on community property incurred prior to separation. In that situation, the court has discretion to allow reimbursement under Marriage of Epstein, 592 P.2d 1165, which displaces Lucas as the controlling case, despite the limitations of $\$ 4800.2$. Green v. Green, 261 Cal. Rptr. 294 (1989); Hebring v. Hebring, 255 Cal. Rptr. 488 (1989).

Other California statutory provisions dealing with specific instances of reimbursement are CAL. CIV. CODE \$\$ 5120.140 (West Supp. 1992) (reimbursement of separate estate for payment of debt for necessaries of life incurred by one spouse if community property or separate property of other spouse was available), 5120.150 (reimbursement of community for payment of a spouse's child or spousal support obligation to extent spouse owing support had separate income), and 5120.160 (reimbursement after division). These three provisions have a special measure of reimbursement and time limit for exercise. Id. \$ 5120,210.

86. See supra text accompanying notes $36-38$.

87. Cal. Civ. CoDE $\S 5103$ (West Supp. 1992).

88. Id.

89. See generally, Oldham, supra note 2 (discussing California's new duty of care). 
California standard would certainly justify greater court scrutiny of reimbursement claims than does Louisiana's fraud or bad faith standard.

\section{$\mathrm{V}$}

\section{Subsisting Profit, NeCESSITY, BenEFIT: THE Rules of FranCE}

In France, the rules of the legal community regime, ${ }^{90}$ as modified in 1985 , provide a general rule for the equal and independent management and disposition of the community property by each spouse, the spouses being liable to each other for "fault." 11 Each spouse also has the right to manage and dispose of his or her separate property ${ }^{92}$ and to consume its fruits, but savings from the fruits and acquisitions made from savings are community property. ${ }^{93}$

The concept of equal and independent management was superimposed in 1985 on the existing reimbursement rules that incorporated the principle that one estate must not gain at the expense of the other. This unjust enrichment principle is expressed in a general rule that reimbursement, whether communityto-separate or separate-to-community, is the lesser of the amount spent or the profit subsisting at partition. ${ }^{94}$ Subsisting profit, where acquisitions are concerned, means an amount equal to a pro-rata share of the present value of the property; ${ }^{95}$ for improvements, subsisting profit is the difference between the value of the property at partition and the value it would have had if the improvement had not been made. ${ }^{96}$ For expenses of preservation, scholarly authority exists for both methods of calculating subsisting profit. ${ }^{97}$ There are two exceptions to the general rule reimbursing the lesser of the amount spent or subsisting profit: reimbursement for necessary expenses cannot be less than the amount spent; and reimbursement for the acquisition, preservation, and improvement of property cannot be less than the amount of the subsisting profit. $^{98}$ Necessary expenses, according to some authorities, extend beyond

90. In France, the "legal regime of the community reduced to acquets" is the regime that applies to the spouses who have married without adopting a matrimonial regime by formal marriage contract. See ANDRE COLOMER, DROIT CIVIL, REgIMES MATRIMONIAUX no. 3 (4th ed. 1990). It corresponds generally to the legal regime of acquets and gains of Louisiana, though the two differ in some respects. See LA. Civ. CodE ANN. arts. 2327-28 (West 1985).

91. C. CIV. art. 1421 (Fr.). "Fault" probably will be limited to serious faults. CoLOMER, supra note 90, at no. 500 .

92. C. CIV. art. 1428 (Fr.).

93. C. CIV. arts. 1401, 1403 (Fr.). The community is due reimbursement if during the five years prior to dissolution a spouse neglected to collect the fruits of his or her separate property or fraudulently consumed them. C. CIV. art. 1403 (Fr.). See COLOMER, supra note 90, at nos. 609-11.

94. C. CIV. art. 1469 (Fr.).

95. COLOMER, supra note 90 . If the property has been disposed of before partition, subsisting profit is calculated as of the day it was alienated; if proceeds have been invested in a new asset, it is calculated based on value added to the new asset. C. CIV. art. 1469 (Fr.).

96. COLOMER, supra note 90 , at no. 987 .

97. Id. at no. 984 .

98. C. CIV. art. 1469 (Fr.); COLOMER, supra note 90, at No. 967-68. 
those incurred to preserve an immovable to any expense vital to person or patrimony. ${ }^{99}$ Payment of mortgage debt-presumably including the interest component - to secure the purchase, preservation, or improvement of property is probably treated under the rules for acquisitions, preservation, and improvements. ${ }^{100}$ Furthermore, although family expenses are community debts, and a spouse who pays a family expense with separate funds is generally entitled to reimbursement, the court may deny reimbursement if the expense did not benefit the community because, for example, it was excessive, or because one spouse made a selfish purchase without consent. ${ }^{101}$ Should the community be exhausted, however, each spouse is obligated to contribute to family expenses in proportion to his or her means. ${ }^{102}$

Had Cabral been decided under French rules, the husband's reimbursement claim would have been limited to the community project's subsisting profit, a fair result since the husband admitted he should have paid more attention to the project he undertook to manage. Family expenses in France are reimbursable, but they are scrutinized for actual community necessity and benefit to prevent extravagances or the selfish desires of a spouse from eroding the community. Such a rule in Louisiana might have reduced the reimbursement claim in Guarisco by making the court scrutinize more carefully the community debts paid with separate property. In France, independence in management during the regime is tempered at dissolution by reimbursement rules that, when applied to separate claims for reimbursement for unsuccessful investments, will make the separate estate bear some of the loss. The measure of reimbursement for investments - the limitation of subsisting profit-is the mechanism for doing so; for family expenses, it is the circumstances entitling a spouse to reimbursement -necessity and community benefit-that reconcile the individual and common interests.

\section{VI \\ ENHANCED VALUE, NECESSITY, FAULT: LOUISIANA'S NEW CO-OWNERSHIP LAW}

In Louisiana, the partition of the community often occurs many months after the termination of the community regime by divorce or death. During the time after the regime is terminated but before the community patrimony is partitioned, one of the spouses will commonly use his or her now separate earnings

99. G. CORNU, LES Regimes MATRIMONIAUX 577 (5th ed. 1989). For example, a surgical operation or the purchase of tools for a spouse's profession are necessary expenses in the view of some French authorities. COLOMER, supra note 90 , at no. 971.

100. See COLOMER, supra note 90 , at no. 985. Payment of a mortgage debt incurred for a purpose other than acquisition, preservation, or improvement of the mortgaged property would be reimbursed depending on whether the debt was "necessary." The payment is not treated as preserving the property simply because it prevents foreclosure.

101. Id. at no. 795-96.

102. C. CIV. art. 214 (Fr.). 
to pay former community debts. The Civil Code's reimbursement rules previously discussed in this article appear to apply only to expenditures during the community regime. Nevertheless, prior to 1991 the Louisiana courts had been applying them to expenditures after termination of the regime. Some courts, however, exercised more freedom to consider equitable factors in the post-termination situation than the code articles allow. ${ }^{103}$

The matrimonial regime's rules on reimbursement are no longer applicable to post-termination situations. Instead, article 2369.1, added to the Civil Code in 1990, effective January 1, 1991, states: "After termination of the community property regime, the provisions governing co-ownership apply unless there is contrary provision of law or juridical act." 104 The official comment states: "After termination of the community, the interests of the former spouses in anything held in indivision are treated as co-ownership." 105 Thus, to the extent that the rules of co-ownership address reimbursement, these rules, not the rules of the matrimonial regime, would determine whether and to what extent reimbursement would be allowed for post-termination expenditures.

Effective in 1991, the Civil Code acquired new rules on ownership in indivision (also called co-ownership) ${ }^{106}$ When one co-owner uses personal funds for the property owned in common, issues arise similar to those raised when a spouse uses separate property for a community acquisition or improvement. ${ }^{107}$ The new co-ownership rules can thus be compared to the reimbursement rules concerning acquisitions and improvements. The new co-ownership rules specify two instances in which a co-owner is entitled to reimbursement: when substantial alterations or improvements of the co-owned property have been made by one of the co-owners; ${ }^{108}$ and when expenses have been incurred by one of the co-owners in connection with the property. ${ }^{109}$

Unlike the reimbursement rules of the community regime, entitlement to reimbursement for substantial alterations or improvements considers whether the alteration or improvement was made with the consent of the other co-owner and, if not, whether the construction was consistent with the use of the property. When an alteration or improvement is made with the consent of the co-owner, or is made without the consent of the co-owner but is consistent with the use of

103. See SPAHT \& HARGRAVE, supra note $16, \S 7.14$, at $289-91$. In the post-termination setting two issues had arisen: (1) whether to permit reimbursement of the full amount of a mortgage payment made on the former community residence (now held in indivision), or only for the principle paid, the reimbursement for interest, taxes, and insurance depending on which spouse had the obligation to provide housing for the occupying spouse, id. at notes 38-47; and (2) whether to deny reimbursement for payments made on a former community auto when the spouse making the payments had exclusive use of the auto since termination of the community. Id. at nn. 48-50.

104. LA. Civ. CoDE ANN. art. 2369.1 (West Supp. 1992).

105. Id. $\mathrm{cmt}$.

106. Id. arts. 797-818, added by 1990 LA. ACTS 990, effective Jan. 1, 1991.

107. Nothing in the co-ownership situation corresponds, however, to use of separate property for family expenses.

108. Id. art. 804.

109. Id. art. 806 . 
the property, reimbursement pursuant to the new co-ownership rules is the least of the following: the cost of the materials, their current value, or the enhanced value of the immovable at the time reimbursement is sought. ${ }^{110}$ If the alteration or improvement was made despite the objection of the other co-owner, or is inconsistent with the use of the property, that co-owner may demand its removal at the expense of the co-owner who made the alteration or improvement, or reimburse the co-owner who made the alteration or improvement for the current value of the materials and workmanship or the enhanced value of the immovable at the time reimbursement is sought, whichever is less. ${ }^{111}$ Thus, under the new rules of co-ownership, reimbursement is always limited to enhanced value and may be completely unavailable in some circumstances.

For other expenses, reimbursement between co-owners depends on the type of expense incurred and whether the co-owner claiming reimbursement has had the enjoyment of the property purchased. Necessary expenses, expenses for ordinary maintenance and repairs, and necessary management expenses paid to a third party are reimbursable, but the party seeking reimbursement must offset the value obtained through enjoyment of the property. ${ }^{112}$ The chief limitation on reimbursement for expenses lies in the definition of a "necessary" expense. "Necessary expenses" are those incurred for the preservation of the property or for the discharge of private and public burdens. ${ }^{113}$ This kind of expense is to be distinguished from "useful" and "luxurious" expenses, ${ }^{114}$ neither of which appears to be reimbursable under the new co-ownership rules.

Thus, a former spouse who uses separate property to alter or improve former community property or to pay newly incurred expenses in connection with former community property will not ipso facto be reimbursed for the amount spent, as he or she would if the alteration or improvement had occurred prior to termination of the community regime. Enhancement and necessity are limitations on reimbursement for post-termination expenditures.

110. Id. art. 496 (West 1980), art. 804 (West Supp. 1992). The articles give the co-owner who owes reimbursement the choice of which amount to pay, but it is reasonable to assume that the least of the amounts will always be chosen.

111. Id. art. 497 (West 1980), art. 804 (West Supp. 1992). The rule described in the text applies to constructions subject to the rules of accession; that is, improvements that do not become merged with the soil, such as houses, carports, or barns. Improvements or ameliorations inseparable from the soil (drainage improvements, for example) are considered "useful expenditures," rather than constructions subject to the accession rules. See id. art. $497 \mathrm{cmt}$. c.

112. Id. art. 806 .

113. Id. art. 527. "Necessary" expenses include property taxes and assessments, indispensable repairs and maintenance costs, and insurance costs, art. $527 \mathrm{cmt}$. b. See also id. arts. 1256, 1259 (West 1987).

114. "Useful expenses" are those that increase the property's value but without which it can be preserved. Id. art. 528 (West 1980), art. 1259 (West 1985). Normally, a possessor of property is entitled to reimbursement from the owner for useful expenses to the extent they have enhanced the property's value. Id. art. 528, art. 1257 (West 1985). "Expenses for mere pleasure" (that is, "luxurious expenses") are those made only for the accommodation or convenience of the owner or possessor and that do not increase the property's value. Id. art. 1259. There is no reimbursement for luxurious expenses, although the maker of a luxurious construction is allowed to remove it if removal will not damage the property. Id. art. 1258 (West 1987). See generally 2 A.N. YianNOPOULOS, LouisianA Civil LAW TREATISE: PROPERTY \& 275 (3d ed. 1991). 
Not all separate claims for reimbursement of expenditures made during the marriage would turn out differently under the new co-ownership rules. The Cabral result likely would be the same. Payment of a mortgage debt attributable to an acquisition or improvement of community real estate probably is treated under the co-ownership rules not as an improvement, for which reimbursement is subject to the enhancement limitation, but as a necessary expense, reimbursable regardless of enhancement. Louisiana's definition of "necessary" expense includes the "discharge of private and public burdens."115 Hence, if the mortgage for the acquisition and improvement is considered a private burden, the co-ownership rules will allow reimbursement for the full amount spent.

One other feature in the new co-ownership law might affect the Cabral outcome. Under new article 799, a co-owner is liable for "damage" to the property caused by his "fault." "Fault" in Louisiana is a concept involving a more stringent standard of care than the "fraud or bad faith" standard applicable between spouses during the community regime. "Fraud" and "bad faith" imply an intent to cause harm, ${ }^{117}$ while "fault" can include not only the intentional causing of harm, but also "the want of care which a prudent man usually takes in his business."118 The official comment to new article 799 indicates that, at least where a co-owner has undertaken to manage the co-owned property, "fault" is to have the meaning that includes the want of care of a prudent man. ${ }^{119}$

If, however, "damage" in new article 799 means only physical damage and does not include economic loss, reimbursement would still be allowed under the co-ownership articles in the Cabral situation, despite the higher standard of care, because the damage in Cabral was economic rather than physical. Damage should include economic loss whenever one of the co-owners undertakes to manage the co-owned project. The types of losses that are actionable should relate to what the co-owner undertook to do. If he or she undertook the general oversight and management of the project, he or she should be liable for the various kinds of losses that can occur, including economic loss. Under this view

115. LA. Civ. CODE ANN. art. 527 (West Supp. 1992).

116. Id. art. 799.

117. See id. art. $1997 \mathrm{cmt} . \mathrm{c}$ (West 1987).

118. Id. art. 3506(13) (West Supp. 1992).

119. The official comment refers to article 576, the standard of care of a usufructuary: fraud, default, or neglect. A co-owner who undertakes to manage is similar to a usufructuary who is in possession of the property. The official comments to the usufruct article describe the standard of care of a usufructuary as "prudent man." Id. art. $576 \mathrm{cmts}$. b \& c (West 1980). Katherine Spaht states that "fault" in new article 799 does not impose on a co-owner a duty to manage. Be that as it may, a reimbursement claim involves a co-owner who has undertaken to manage the co-owned property by using his or her personal funds on the co-owned property. Katherine Spaht, Developments in the law 1989-90: Matrimonial Regimes, 51 LA. L. REv. 321, 331 (1990). In the situation of a co-owner who has undertaken to manage the property, the "fault" standard should make the co-owner liable for the want of care to be expected of a prudent man. As Spaht points out, prudent administration was the standard applicable prior to the enactment of article 799 under the law of quasi-contract to a co-owner who undertook to manage the co-owned property. Id. at 331. Thus, the "prudent man" or "prudent administrator" standard is not new in the context of a co-owner who undertakes to manage. 
of "damage," the reimbursement claim of a co-owner who undertook to manage the co-owned project, but whose neglect allowed economic losses to mount, would be offset, at least to some extent, by the loss neglect had caused. An analogous situation to that of the co-owner who undertakes to manage is that of the quasi-contract, known in Louisiana as negotiorum gestio, or management of the affairs of another. Such a manager is entitled to the reimbursement of expenses only if he or she has managed as a "prudent administrator."120 The broad interpretation of "damage" applied whenever a co-owner has undertaken to manage the co-owned property is consistent with the concept of prudent administration in the law of quasi-contract. If the analogy is correct, the fault standard of care would give a court more leeway to limit or deny reimbursement in a case such as Cabral.

Under the new co-ownership law, the rules of reimbursement that utilize enhanced value and necessity as limitations are drawn directly from the law of accession, a body of law that is permeated with the principle of unjust enrichment. ${ }^{121}$ These rules of accession are rejected by the community regime's rules, which instead provide reimbursement of the amount of separate property used. ${ }^{122}$ Now that the unjust enrichment principles have resurfaced in the marital context to govern the rights of ex-spouses who co-own unpartitioned community property, the wisdom of the rejection of these principles in the community regime ought to be reexamined. One might also question why there should be two different standards of care, one during marriage and the other after termination, applicable to a spouse who undertook to manage by using his or her separate property for community or former community obligations or property, ${ }^{123}$ and why the same standard in both cases should not be "fault."

\section{VII \\ REVISION OF LOUISIANA'S RULES}

The rules governing separate claims to reimbursement ought to protect the community interest of the nonclaimant spouse more than they do at present. As

120. LA. Civ. CODE ANN. art. 2298. The standard of care is so high that article 2298 permits the court to be lenient where the gestor (manager) undertook the management out of friendship or necessity.

121. Symeon Symeonides, Developments in the Law 1983-84: Property, 45 LA. L. REV. 541, 546 (1984). In the French civil law of unjust enrichment (known as the actio de in rem verso), one seeking recovery must show that enrichment still exists at the time the action for reimbursement is brought, not merely at the time the expenditure is made. Barry Nicholas, Unjustified Enrichment in the Civil Law and Louisiana Law, 36 TUL. L. REV. 605, 645 (1962). The pre-1980 community property jurisprudence imposing the requirement of continuing benefit to the community upon a husband claiming reimbursement for his separate estate was thus consistent with the civil law of unjust enrichment and accession.

122. See LA. Civ. CODE ANN. art. $2367 \mathrm{cmt}$. Symeonides, supra note 121, at 554; Katherine Spaht, Developments in the Law, 1983-84: Matrimonial Regimes, 45 LA. L. REV. 417, 418-19 (1984).

123. See Katherine Spaht, Post Dissolution Management of Former Community Property: An Unresolved Problem, 1990 WIS. L. REV. 705 (1990) (praising California Civil Code $\$ 5125$ as amended in 1986 extending the standard of care then applicable in California to management during the marriage [good faith between persons having relationships of personal confidence] to the management of former community property until it is divided). 
a political matter, the smaller the change in the present rules necessary to achieve this goal, the more readily it will be accepted. After all, the present rules are not yet old. It is unlikely that legislative energy and enthusiasm could be summoned in favor of a major overhaul so soon after the intense legislative process that culminated in the system of which the present reimbursement rules are a part. Thus, political reality is currently a limitation on the optimal revision.

The present rules are as simple as reimbursement rules can possibly be. Any revision to do greater justice to the community would add complexity to the code articles. One way to avoid complicating the rules would be to authorize the judge to weigh, on a case-by-case basis, the equities when reimbursement is sought. The judge would simply have discretion to limit or deny reimbursement as equitable factors would seem to warrant, much like the power the judge has under some versions of equitable distribution of property at divorce. ${ }^{124}$ Such broad judicial discretion, however, makes outcomes less predictable and settlement harder to achieve. ${ }^{125}$ This result would be inconsistent with Louisiana's 1980 attempt to create a comprehensive set of fixed rules to govern marital property disputes. It is preferable to accept some complexity in the rules in an effort to make the fixed rules more fair than to dump yet another problem in the lap of the judge as weigher of equities.

A similar danger of increased litigation inheres in raising the standard of care in the management of the community property during the marriage from avoidance of fraud and bad faith to the more stringent "fault" standard. "Fault" is the standard of care owed between the former spouses after termination of the regime under the new co-ownership articles. ${ }^{126}$ Even people with no previous legal relationship to each other may owe each other this standard of care. ${ }^{127}$ Ideally, spouses should owe each other at least this standard of care during the marriage. Perhaps the risk that "fault" in the management of the community property would become an issue in the termination of every community regime is too much for the judicial system to bear. But it might not offend judicial economy for "fault" to be the standard applied to a spouse seeking reimbursement for separate funds spent on a community enterprise or investment, the management of which was undertaken by the claimant spouse. If the fault of the spouse seeking reimbursement is present in the circumstances occasioning the use of his or her separate property, reimbursement could be limited or denied. Thus, a spouse managing community property who negligently incurred or extended community obligations might only receive partial reimbursement, or none at all, for separate property that was applied to those obligations. If restricted to

124. Martha Fineman, Societal Factors Affecting the Creation of Legal Rules for Distribution of Property at Divorce, 23 FAM. L.Q. 279, 284-86 (1989).

125. See J. Thomas Oldham, Tracing, Commingling, and Transmutation, 23 FAM. L.Q. 219, 249-50 (1989); Mary Ann Glendon, Fixed Rules and Judicial Discretion in Contemporary Family Law and Succession Law, 60 TUL. L. REV. 1165 (1986).

126. See supra text accompanying notes 116-23.

127. LA. CIv. CodE ANN. art. 2315 (West Supp. 1992): "Every act whatever of man that causes damage to another obliges him by whose fault it happened to repair it." 
claims for reimbursement, "fault" could serve as a check on the fairness of the claim without overburdening the system.

A requirement of consent by the spouse against whom reimbursement is claimed also seems an advisable basic protection if reimbursement is to be allowed for separate funds spent on a community investment regardless of the success or failure of the investment. But a consent requirement raises several additional questions. How must consent be manifested? Will confirmation (that is, ratification), authorization, or estoppel suffice for consent? To what must the consent pertain? The initial acquisition? Subsequent management decisions as well? As with the issue of fault, if protection of the community interest of the spouse against whom reimbursement is claimed could be achieved without injecting litigious issues such as consent, so much the better.

From among the methods of protecting the community that do not involve litigating fault or consent, one is tempted to choose, with respect to reimbursement for acquisitions and improvements, a measure of reimbursement limited by the enhancement to the community. If Louisiana had a clean slate upon which to write reimbursement rules, one might advocate adopting the French subsisting profit approach to calculating reimbursement. A pro-rata reimbursement approach, similar to the French approach to acquisitions, has been adopted in Arizona for those situations when community funds have made payments on a purchase money mortgage on separate property. ${ }^{128}$ Alternatively, Louisiana could adopt the enhanced value limitation on the amount to be reimbursed from the new Louisiana law of co-ownership. However, in 1979 enhancement was specifically rejected by the Louisiana legislature as the measure of reimbursement.

It would probably be easier politically to build upon the approach of reimbursing the "amount or value [of separate property] ... that ... was used" that is already in place in Louisiana. Louisiana could easily borrow from California, since California now uses this approach at divorce or judicial separation for acquisitions and improvements of community property made with separate funds. ${ }^{129}$ The second sentence of the first paragraph of Louisiana's article 2367 should be deleted and replaced with the following sentence adapted from California's Civil Code section 4800.2: "The amount reimbursed shall not exceed the net value of the thing for which the separate property was used." This change would prevent the reimbursement claim on a losing project from exceeding the value of that project, thus causing other community property to be used to satisfy the reimbursement claim. It should also be made explicit, as

128. See Drahos v. Rens, 717 P.2d 927 (Ariz. Ct. App. 1985) (giving reimbursement to the community calculated on a pro-rata basis). California, Nevada, and New Mexico give the community a pro-rata share of ownership instead of reimbursement. Marriage of Moore, 618 P.2d 208 (Cal. 1980); Malmquist v. Malmquist, 792 P.2d 372 (Nev. 1990); Dorbin v. Dorbin, 731 P.2d 959 (N.M. Ct. App. 1986). See William A. Reppy, Jr., Repayment with Community Funds of Consumer Loans Secured by Separate Realty: Seeking the Appropriate Remedy, 14:4 COMMUNITY PROP. J. 1 (Jan. 1988) (comparing pro-rata approaches).

129. See supra text accompanying notes 83-86. 
it is in California, that payment with separate property of a debt related to a community acquisition or improvement falls under this rule and not under a different rule for payment of debts. Finally, it may also be desirable to specify, as does California, that reimbursable expenditures include only those that add to the equity in the property, not expenditures for interest, taxes, maintenance, or insurance. This gives the community the maximum interest in the property consistent with allowing some reimbursement to the separate estate. This last provision is not as critical a change as the limitation of reimbursement to the net value of the asset on which the separate expenditure was made. It could be eliminated if legislators thought it to be too harsh on the separate estate. ${ }^{130}$

As for reimbursement for family expenses, California's law suggests that when a spouse has opted unilaterally to reserve the fruits from separate property as separate, as in California where such fruits are automatically separate, he or she ought not to be entitled to reimbursement for separate property used for family expenses. The reasoning for this rule would not be the same in Louisiana as it is in California - that is, that the separate property is deemed to have been donated to the community-rather, Louisiana's reason would be that a spouse should not be able unilaterally to withhold the fruits from the community and claim reimbursement. Reimbursement would be available only to a spouse who had generously made the fruits of his or her separate property available to the community for investments and family expenses, or where both spouses agreed that a spouse need not contribute the fruits of his or her separate property.

A rule such as California's family expense rule would be difficult to apply in Louisiana because, under Louisiana's article 2339, a spouse may reserve the fruits of some, but not necessarily all separate property. Would it be fair to invoke a no-reimbursement rule if the fruits of ninety percent of the separate property still accrued to the community? Fifty percent? In such cases, and in cases where both spouses agree that the fruits of separate property of the reimbursement claimant will be separate, or where the fruits are community under the general rule, some reimbursement ought to be given for family expenses. It is thus sensible to allow reimbursement for family expenses in all cases, but to make the measure of reimbursement the device for preventing easy depletion of the community property remaining at divorce.

Louisiana could emulate France, placing the burden on the courts to scrutinize the amount claimed and the purpose of the expense to determine whether it was "necessary" or beneficial. Absent guidelines, however, this approach would inject uncertainty into the law similar to that found until

130. Arguably, reimbursement to the separate estate should include interest, taxes, and insurance not to exceed the net value of the property. The community, not the separate estate, has had the use of the separate funds spent on the community property. This is true even if the spouse whose separate funds were spent occupied the community property on which the separate funds were spent, for during the marriage, living accommodations are a community responsibility. If the community property upon which the separate funds were used generated income, the income was community property. Having received no benefit from the separate funds once they were spent on the community property, the separate estate owes no offset against its claim for reimbursement for all amounts spent. 
recently in the area of child support. ${ }^{131}$ A more objective measure of reimbursement, if also fair, is preferable to a less objective measure that would increase litigation.

When community property remains after deduction of obligations to third parties and reimbursement for acquisitions and improvements, the community ought to reimburse the separate estate for family expenses because it can afford to do so, provided reimbursement does not exhaust the community. An objective method of determining the amount that reimbursement should not exceed is necessary. One possible rule would be to allow reimbursement in an amount not to exceed a legislatively determined fraction of the remaining community property, such as one-fourth or one-third. Application of this rule has the advantage of not involving any discovery or valuation of property beyond what is already necessary in a partition. Determination by the legislature of a fraction of available property is a method commonly employed in Louisiana for establishing the fair amount of a claim. In Louisiana inheritance law, forced heirs are entitled to claim a certain fraction of the decedent's estate. ${ }^{132}$ Also, the present Louisiana Code article concerning postdivorce alimony limits the amount owed to one-third of the payor's income. ${ }^{133}$ Similarly, the "marital portion," that is, the claim of a surviving spouse from the succession of the wealthy deceased spouse, is likewise a legislatively determined fraction. ${ }^{134}$ This fractional method of limiting the reimbursement claim for family expenses could easily be incorporated into article 2365 , which concerns family expenses, by amending the second paragraph to read: "Nevertheless, if the community obligation was incurred for the expenses of the marriage, or for the support, maintenance and education of the children of either spouse, the amount of reimbursement shall not exceed [some fraction] of the community after deduction of all community obligations and reimbursement due under article 2367."

Another method for determining the maximum reimbursable fraction of remaining community property is to use the ratio of the separate funds spent on family expenses to the total income during the marriage, separate plus community. Proof of the separate and community income on hand during the marriage could be obtained from income tax records, which would not add greatly to the present burden of discovery in partitions. The results produced under this second fractional method might seem as arbitrary as those under the first fractional method, in the sense that the method ignores the actual availability of separate and community funds at any particular time during the marriage. It also ignores proof that the remaining community property is in fact traceable only to a community source, as when, one month prior to termination, a spouse received a large contingent fee. Yet proportionality is already a

131. See Oldham, supra note 125 , at 250.

132. LA. Civ. CODE ANN. art. 1495 (West Supp. 1992).

133. Id. art. 112.

134. Id. art. 2434. 
concept accepted in Louisiana's community property law in the context of the authority of one spouse, acting alone, to make usual or customary gifts of community property. Under Civil Code article 2349, if made by one spouse alone, such gifts must be of a value "commensurate with the economic position of the spouses at the time of the donation." The Code intentionally used the term "spouses," rather than "community," to make the separate property of the spouses, not just the community property, relevant to how much community property a spouse may give away without the other spouse's consent. A separately wealthy spouse, for example, should be more limited in the amount of community property he or she can give away without the other spouse's consent than if he or she had no separate property, especially if the other spouse has no separate property. ${ }^{135}$

The proportionate reimbursement concept could be embodied in the following amendment to Civil Code article 2365, again with as little change in the language of the present article as possible:

\begin{abstract}
If separate property of a spouse has been used to satisfy a community obligation other than an obligation for the acquisition, improvement, use, or benefit of a community thing, that spouse, upon termination of the community property regime, is entitled to reimbursement from the other spouse of one-half of an amount equal to a portion of the community property remaining after deduction of all community obligations to third persons and amounts spent for which reimbursement is due under article 2367 . The portion shall be in the ratio that the separate funds used by the spouse claiming reimbursement bears to the sum of the separate and community income on hand during the marriage. The amount of reimbursement shall not exceed the amount spent.
\end{abstract}

The following hypotheticals demonstrate how this proposal would operate. Assume that the total of the community income of the spouses during the marriage was $\$ 100,000$. During the marriage, the wife's sole separate property was inherited stock that she sold for $\$ 50,000$. She proves that she spent $\$ 40,000$ on family expenses and $\$ 10,000$ on an improvement of a piece of community property. At termination, the entire community, net of debts to third persons, is worth $\$ 50,000$. Under present law, the wife's total reimbursement claim of $\$ 50,000$ would exhaust the community property. Under the proposal, however, she would receive reimbursement of $\$ 10,000$ from the remaining community for the improvement. That would leave a community of $\$ 40,000$. Of this, her reimbursement portion from the undivided community would be $26.67 \%(40,000$ $+150,000$ ) or $\$ 10,668$. The remaining $\$ 29,332$ would be community property to be divided equally. The husband would thus end up with $\$ 14,666$, rather than zero. $^{136}$ If, after termination, the community had been worth $\$ 1,000,000$, the

135. See Oldham, supra note 2 (discussing the Texas proportionality test for the reasonableness of a gift of community property).

136. The present articles on reimbursement are formulated in terms of spouse-to-spouse, rather than community-to-spouse reimbursement, as if each spouse receives half of the community property net of debts to third parties, and then pays reimbursement out of his or her half. To be consistent with the present formulation, the proposed formulation states the formula for reimbursement in spouse-to-spouse 
wife would have been reimbursed the full $\$ 40,000$ she spent on family expenses. ${ }^{137}$

If no community property remains after deduction of debts to third parties and reimbursement for acquisitions and improvements, under the fractional proposals the spouse who spent his or her separate funds on family expenses would not be entitled to reimbursement. This result is contrary to the second paragraph of present article 2365 , which obligates a spouse to pay reimbursement for, among other things, ordinary and customary expenses of the marriage, even though the community property is exhausted. If the community has reached the point of insolvency, the burden of these expenses should be left where it lay: upon the spouse who paid them with separate property. The second paragraph of present article 2365 should thus be deleted.

\section{VIII \\ CONCLUSION}

As one who participated in the writing of the legislation that eventually became Louisiana Civil Code articles 2325-2347, the author feels a special responsibility to urge modification of any of the rules that, in practice, have caused or may cause hardship to a spouse whose only asset is his or her community interest. ${ }^{138}$ Equal management ought not to have left the community at partition so vulnerable to the spouse claiming reimbursement of his separate estate, yet some reimbursement is appropriate. Without engendering too much additional discovery or litigation, reimbursement for separate funds

terms. Thus, the spouse owing reimbursement pays one half of the amount to be reimbursed to the other spouse. As applied to the example in the text, the spouse-to-spouse formulation means that the husband pays a total of $\$ 10,334$ in reimbursement $(\$ 5000+\$ 5334)$ from his $\$ 25,000$ half of the community net of obligations to third persons, leaving him with $\$ 14,666$.

137. A different fractional approach is suggested by a student comment. The author explained his pro-rata theory in terms of a "savings-ratio." The community property on hand at dissolution is the savings from the total community and separate income on hand during the marriage. The ratio of the remaining property to the total of community and separate income during the marriage is the "savings ratio." This ratio multiplied by the separate income equals the separate savings (and hence the amount of separate reimbursement); multiplied by the community income equals the community savings (and hence the amount of community property that will be divided after reimbursement). The author suggests, however, that the savings ratio of the particular family might be modified by averaging it with the average savings ratio of a family having the same total income, the second ratio to be obtained from statistical data. Ehrenpries, Comment, supra note 78.

138. The author was a member of the advisory committee to the Joint Legislative Subcommittee on Community Property, 1978-79. The advisory committee and joint subcommittee produced 1978 Louisiana Acts No. 627, the equal management reform, containing the precursors of the reimbursement articles discussed herein. Between the 1978 and 1979 legislative sessions, the Louisiana State Law Institute was directed to redraft the legislation to conform its style to the Civil Code, but without changing the policy decisions embodied in Act 627. The present Code articles are thus the work of the Louisiana State Law Institute in style, but not in substance. The writer recalls hardly any discussion in the advisory committee or joint subcommittee of the reimbursement rules. Time was short; the case of Kirchberg v. Feenstra, 450 U.S. 455 (1981), which ultimately declared Louisiana's husband-management system unconstitutional, was pending. Thus, the committee's attention was focused on the effect of equal management upon the spouses' interaction with third parties, rather than the effect between the spouses. See generally Symposium on Community Property, 39 LA. L. REV. 323 (1979). 
used for community investments could be limited to the net value of the property upon which the separate funds were spent, and the separate estate could be reimbursed an amount for separate funds spent on family expenses not to exceed a fractional share of remaining community assets. Reimbursement for family expenses after the community is exhausted should not be permitted. As extra protection for the community, the standard of care in the management of the community property applicable to a spouse who claims reimbursement of his or her separate estate should be upgraded to "fault" in the sense of prudent administration. These adjustments to the existing law would help restore the primacy of the spouses' common endeavor, represented by the community property, over a spouse's separate endeavor. 
